\title{
DIE TOEKOMS VAN DIE GEESTESWETENSKAPPE
}

\author{
H.F. VAN ROOY, Dept. Semitiese Tale, PU vir (IHO
}

\section{ABSTRACT}

The humanities are today being threalened by the overwhelming demand for manpouter for the industries, the demands of professionalising and of national interest in South Africa. The danger in this lies in the fact that the balance in society may be upset, at the cost of the cultural development of the people. The ideal of universal man is being relinquished more and more at the cost of specialization in the sciences. There is thus a very real need today that the humanities should not be neglected, but should rather be studied more intensively.

Dic toekoms van die geesteswetenskappe in Suid-Afrika is 'n saak wat dic afgelope tyd heelwat aandag geniet. Uit verskeic oorde word die gecsteswetenskappe inderdaad bedreig, aan universiteite veral deur die eis tot professionalisering, waardeur basiese wetenskaplike onderrig en vorming ondergeskik gestel word aan die eise van verskillende beroepe.

In die lig van hierdic vraagstuk moet die belangwckkende rede van prof. F.C. Fensham, voorsitter van die $R$ aad van die Suid-Afrikaanse $\Lambda$ kadcmie vir Onderwys, Kuns en Wetenskap, by dic jaarvergadering van die Akademie in 1982 gesien word. Prof. Fensham, hoof van die departement Semitiese tale aan die Universiteit van Stellenbosch, het in die rede die kern van die saak aangeraak. Die rede sal wel deur die Akademie gepubliseer word, maar die redaksie van Koers ag dit van sovecl belang dat, met prof. Fensham sc toestemming, ruim uit sy rede aangchaal word*.

Die probleem van die geesteswetenskappe in Suid-Afrika moet gesien word teen die lig van die vinnige industriële ontwikkeling in Suid-Afrika en die gepaardgaande vraag na mannckrag:

"In omstandighede soos hierdic word hoog gebie vir mannckrag, veral kundige mannekrag. Die klein grocpie intelligentsia en opgeleides moet werk rloen vir miljoene mense wat swak opgelei is of glad nie opgelei is nie. Vir'n land wat industricel ontwikkel, word'n hoë premie geplaas op mense wat in die tocgepaste wetenskappe gestudeer het of wat op cen of ander wyse

- Aanhalings word gemaak uit 'n afskrif vau die rede wat prof. Fensham self goedgunstiglik tot die skrywer se beskikking gestel het.

Koers, 47(3) 1982 


\section{Van Rooy}

berocpsmatig opgclei is. En saam met dic ontwikkcling van die industricë ontwikkel die sakewêreld. Die gefabriseerde produkte moct van die hand gesit word en les bes die industrieč moet op 'n sakegrondslag bestuur word. Op die industriële en sakevlak is daar rooskleurigc looplane vir talentvolle jongmense. Daar is uitstekende besoldiging vir hulle wat in bepaalde tocpasbare rigtings opgelei is. Trouens, daar is sterk kompetisie met te vecl poste en weinig aansocke. Dit stoot salarisse onrealisties hoog op. In ons samelewing is dit presies hier waar die trekkrag lê. Ons intellektueel hoogstaande en selfs gemiddeldes word hierheen gelok. En ons kan hulle dit nie verkwalik nie. Hulle lewer'n uiters noodsaaklike diens.

"En wat van die geesteswetenskappe? Is dit nie so dat hierdie rigtings dikwels maar met die krummels tevrede moet wees nie? Af en toe kan dit gebeur dat ' $n$ begaafde hom geroepc voel om in hierdic rigting te gaan. Vir die gecsteswetenskappe en dus ook goed gebalanseerde ontwikkeling van ons land, bly dit 'n ernst ige probleem. Die dolle gejaag agter mannckrag gee weinig gelecntheid vir besinning oor'n gebalanscerde verdeling van talente tussen die kompeterende rigtings in ons volkshuishouding. Die land moet voort op sy pad van industriële ont wikkeling. Dit kan ons nie keer nie. Maar, moet ons ons sicl verloor in die proses?"

Hierdie agteruitgang in die geesteswetenskappe kan wel histories beoordecl word. In die verlede - verre verlede maar ook resenter - is baie klem op'n omvattende opvoeding gelê, sodat daar uit die geskiedenis na baie figure verwys kan word wat op een gebied groot lioogtes bereik het maar wat ook op vele ander terreine goed onderlê was. Die saak van opvoeding het baie wyer gestrek as wat vandag die geval is:

"Hierdie tradisie van 'n wye opvoeding het vir'n lang tyd voortbestaan. In Engeland het dit aanleiding gegee tot 'n opvoeding in die "liberal arts", veral aan die Universiteite van Oxford en Cambridgc. Met die oorname van die Kaap deur die Engelse het daardie ideale ook na Suid-Afrika oorgewaai. Soos reeds gesce, was hierdie benadering goed bekend in Nederland. Daar was dus geen weerstand om daarby aan te sluit nie. Dit het hoogty gevier in die beroemde skool Tot Nut van t'Algemeen waar baie Afrikaners vrocg in die vorige ecu opgevoed is en ook in Het Witte Huis waar dr. A. Changuion onderwys gegee het. Dieselfde tradisic is voortgesit aan die Suid-Afrikaanse Kollege (later die Universiteit van Kaapstad) en die Victoria Kollege (later die Universiteit van Stellenbosch)". "Die ideaal wat 'n mens ook by Goethe, Schiller e.a. aantref, was om so opgevoed te word dat jy 'n universcle mens is, in Italiaans uomo universale. Dit is ' $n$ idcaal wat sy invloed tot in ons tyd laat 
gcld het." In dic Suid-Afrikaanse geskicdenis was daar heelparty figure in wie hierdie ideaal verwesenlik is. Dit geld ook van persone wat aan die PU vir GHO verbonde was, soos J.D. du Toit, L.J. du Plessis en J. Chr. Coctzec. Hulle was werklik "universele mense".

Vandag word daar egter ander eise deur die samelewing gestel, sodat spesialisasic al hoc meer dic wagwoord geword het:

"Ons tyd het so gespesialiseerd geword dat die universele mens vinnig besig is om te verdwyn. 'n Mens kan ook begryp dat in 'n tyd waarin vakgebiede almeer uitgebreid raak en ook in diepte toeneem, dit moeilik is om een vakgebicd volkome te beheers. Die neiging is dan om jou toe te spits op 'n sekere afdeling van 'n vak, bv. om te konsentrcer op $A$ frikaanse taalkunde of letterkunde. In die letterkunde kan jy bv. wecr spesialiseer in poësie of prosa. Is dit 'n gocie ontwikkeling? Is ons op die regtc pad met ons opvoeding? Ek wil dit met twee on gesegdes illustreer. In hierdie gesegdes word daar gewaarsku teen uiterstes. Ons moet daartecn waak om al minder van al meer en meer te weet sodat ons naderhand niks van alles weet nie. Maar ons moet ook daarteen waak om al meer van al minder en minder te wect dat ons uitcindelik alles van omtrent niks weet nie. Dit is vervlakking teenoor oorspesialisasie. Vervlakking skep die wanindruk dat ' $n$ mens geweldig baie weet en tog het niks daarvan enige diepte nie. Oorspesialisasie beteken dat hy volkome beheer oor 'n klein onderafdeling van 'n vak het, maar 'n ignoramus is as dit by enige iets anders kom. Hierdie oorspesialisasic veroorsaak dat icmand weinig buite sy vakgebied lees. Dic gevolg hiervan is gcbrek aan perspektief, 'n verengde siening van alles. En so is die lewe nie. Die Vader het aan ons die volle lewe gegee om te geniet en diensbaar aan die mensdom te maak. Hierin spcel dic gecsteswetenskappe 'n wesenlike rol".

Dit is daarom noodsaaklik dat die eie plek van dic geesteswetenskappe - en hulle eic aard - raakgesien moet word. Geesteswetenskappe en natuurwetenskappe het elk 'n eic plek, eje taak en eic metodes - en albei is nodig om die volle werklikheid in diens van God se koninkryk te ont plooi. Ook hier is dit ' $n$ saak van balans, 'n balans wat vandag egter bedreig word deur' $n$ nuwe modewoord: landsbelang:

"In die afgelope tyd het ons gehoor en gelees dat ons met die werwing van mannekrag moet konsent reer op dit wat van landsbelang is. Hicrdie begrip 'landsbclang' word gewoonlik nie omskryf nic, maar dit word in so 'n verband gebruik dat 'n mens met 'n stok kan voel dat sekere geesteswetenskappe uitgesluit is. Is filosofie van landsbelang? Or die tcologie? Wat 


\section{Van Rooy}

van tale soos Akkadics, Sumeries, Sanskrit of Hetities? Die gecsteswetenskaplike voel naderhand eintlik skuldig dat hy met iets besig is wat niks met landsbelang te doen het nie. Wat is dic belangrikste? Is dit belangriker om 'n kanon te ont wik kel wat sclf verder as dic beste Russiese model kan skict of om Akkadiese spykerskrif mocisaam te lees? Ek dink nie dit is reg om hierdie sake teenoor mekaar te stel nie. Wanneer ons 'n gesonde balans wil handhaaf, is albei van landsbelang. Die geesteswetenskappe met hulle talle vertakkinge $\mathrm{en}$ breё spektrum is van die belangrikste boustene in dic breë kultuur van dic volkshuishouding. Om dit in al sy fasette te ontwikkel is om die mense van ons land kulturecl te laat asemhaal. Hoe meer die kulturele longe van dic volk tot in elke hoek asem kry, hoe beter kan ons ont wikkel om breë perspektiewe van die lewe te kry wat ons in ons veelvolkige gemeenskap so nodig het vir oorlewing".

Deur die verwaarlosing van die geesteswetenskappe word algaande die balans in die volkshuishouding benadecl en die deur vir matcrialisme geopen. Dic eise van "landsbelang" en die vraag na hoërvlakmannekrag in Suid-Afrika hou die gevaar in dat die atmosfeer vir dic ontplooiing van die gecsteswetenskappe al hoc swakker word:

"Die at mosfeer wat hier geskep word, gee'n mens 'n benouenis om dic hart. Die algemene klimaat is wcinig bevorderlik vir die bestudering van die geesteswetenskappe en het ookal begin draai teen die teoretiese natuurwetenskappe. Dic klem val swaar op industric̈le ontwikkeling. Die klem val ook daar waar groot geld gemaak kan word. Ons samelewing word al meer matcrialistics ingestel. Dit werk dwarsdeur al die strukture van ons samelewing. As 'n bloedjong mannetjie sulke voordele uit 'n pos kan haal dat hy in ' $n$ pale is van ' $n$ lıuis in ' $n$ spog voorstad kan woon, boonop 'n reuse strandhuis in Plettenbergbaai kan bekostig, elke oggend die keuse tussen drie luukse motors kan maak om werk toe te ry, is daar duisende ander jongmanne wat met begerige oë na hom kyk en ook in daardie rigting wil gaan om te sien of hulle dit nie kan bereik nie. Wat is 'n onderwysertjie, predikantjic en selfs 'n professortjic in die omstandighede? Dit is nic 'n gesonde atmosfer om rekrute vir dic geesteswetenskappe te werf nie. Dit is 'n ongesonde, onnatuurlike atmosfeer wat op ander minder bevoorregte bevolkingsgrocpe ' $n$ indruk maak. Dic rykdom van ons land kan ook sy grootste vloek word. Hiermee wil ck nie die probleem probeer wegdink of impliseer dat 'n mens net die towerstaf kan swaai van die geesteswetenskappe en die probleem is opgelos nie. Dit is baie meer ingewikkeld as dit". 


\section{Toekoms van die geesteswetenskappe}

Daar sal dus in Suid-Afrika 'n besondere poging aangewend moet word om die balans te bewaar en die geesteswetenskappe tot lulle reg te laat kom.

Prof. Fensham het bclangrike vrac aan die orde gestel, en die skoucr sal aan die wicl gesit moet word. Alhoewel die invlocd wat van die regering kan uitgaan, belangrik is, is dit 'n saak hierdie waarvoor persoonlike verantwoordelikheid 'n besondere vereiste is. Die gelowiges het inderdaad die taak om God se koninkryk oor alle lewensterreinc uit te brei. Daar is dus 'n taak op die terrein van die nywerheid, die natuurwetenskappe en die tegniek - maar nooit mag ontwikkeling daar ten koste van die geesteswetenskappe nagejaag word nie. Die hele wêreld win en aan jou sicl skade ly bly vandag nog net so 'n waar woord as 2000 jaar gelede. 